\title{
Seroprevalence of caseous lymphadenitis in goats sold in an animal fair in the northeastern semi-arid region of Brazil
}

\section{Soroprevalência da linfadenite caseosa em caprinos comercializados em feira de animais no Semiárido nordestino}

\author{
José Romero Alexandre Alves ${ }^{1}$; Areano Ethério Moreira de Farias ${ }^{1}$; Geilson \\ Manoel de Souza Lima²; Clécio Henrique Limeira ${ }^{3}$; Francisco Selmo Fernandes \\ Alves $^{4}$; Raymundo Rizaldo Pinheiro ${ }^{4}$; Patrícia Yoshida Faccioli-Martins ${ }^{4}$; Sérgio \\ Santos de Azevedo ${ }^{5}$; Clebert José Alves ${ }^{5 *}$
}

\begin{abstract}
Goat farming in the northeastern regions of Brazil plays an important role in the socio-economic functions of the country. However, high rates of morbidity and mortality occur in the animals, caused primarily by infectious diseases like caseous lymphadenitis, which is widespread in goat herds; this causes serious economic losses to the farming business. Although events such as animal fairs are common in the region, wherein most of the goats and sheep are sold, the risk of disease transmission remains, since the health condition of the animal is unknown. The aim of this study was to determine the frequency of anti-Corynebacterium pseudotuberculosis antibodies present in the goats sold at the animal fair of Tabira - PE, Northeastern semi-arid. Serum samples from 233 goats were collected from the period of November 2014 to June 2015. The diagnosis of infection by C. pseudotuberculosis was made using the indirect ELISA technique. The number of goats seropositive for C. pseudotuberculosis was identified as $87(37.34 \% ; 95 \% \mathrm{CI}=31.38-43.71 \%)$. Of the nine flocks evaluated, five $(55.55 \%)$ were positive. Thus, it is suggested that infection by $C$. pseudotuberculosis is widespread in the goats sold at the animal fairs in the semi-arid Northeastern, reinforcing the need for disease diagnosis in goat herds in the region for the possible implementation of disease control programs.
\end{abstract}

Key words: Agglomerations. Caseous lymphadenitis. Goats. Serology.

\section{Resumo}

A caprinocultura se destaca na região Nordeste do Brasil por desempenhar importante função socioeconômica. Contudo altas taxas de morbidade e mortalidade ocorrem nas propriedades causadas principalmente por doenças infecciosas, destacando-se a linfadenite caseosa, que se encontra amplamente

\footnotetext{
1 Discentes, Curso de Doutorado, Programa de Pós-Graduação em Medicina Veterinária, Universidade Federal de Campina Grande, UFCG, Patos, PB, Brasil. E-mail: j.romeroalves@bol.com.br; areanomv@yahoo.com.br

2 Técnico em Defesa Agropecuária, Agência de Defesa e Fiscalização Agropecuária de Pernambuco, ADAGRO, Pernambuco, São José do Egito, Brasil. E-mail: geilsonmsl@hotmail.com

3 Prof., Instituto Federal de Educação, Ciência e Tecnologia do Pará, IFPA, Santarém, PA, Brasil. E-mail: cleciolimeira@hotmail. com

4 Pesquisadores, Empresa Brasileira de Pesquisa Agropecuária, EMBRAPA Caprinos e Ovinos, CNPC, Sobral, CE, Brasil. E-mail: selmo.alves@embrapa.br; rizaldo.pinheiro@embrapa.br; patricia.yoshida@embrapa.br

5 Profs., Programa de Pós-Graduação em Medicina Veterinária, UFCG, Patos, PB, Brasil. E-mail: sergio@vps.fmvz.usp.br; clebertja@uol.com.br

* Author for correspondence
} 
difundida nos rebanhos caprinos, acarretando sérios prejuízos econômicos à atividade. Eventos do tipo feira de animais são comuns na região, onde é comercializada grande parte da produção de caprinos e ovinos, porém existe um risco de transmissão de doenças nesses locais quando a condição sanitária dos animais é desconhecida. O objetivo desse estudo foi determinar a frequência de anticorpos anti -Corynebacterium pseudotuberculosis em caprinos comercializados na feira de animais do município de Tabira-PE, Semiárido nordestino. Foram coletadas amostras de soro de 233 caprinos no período de novembro de 2014 a junho de 2015. O diagnóstico da infecção por C. pseudotuberculosis foi realizado pela técnica de ELISA-indireto. Foram identificados 87 (37,34\%; IC 95\% = 31,38 - 43,71\%) caprinos soropositivos para C. pseudotuberculosis. Dos nove rebanhos avaliados, cinco $(55,55 \%)$ resultaram positivos. Sugere-se que a infecção por $C$. pseudotuberculosis encontra-se disseminada nos caprinos comercializados em feiras de animais do Semiárido nordestino, reforçando a necessidade do diagnóstico da enfermidade em rebanhos caprinos da região para possível implementação de programas de controle da doença.

Palavras-chave: Aglomerações. Caprinos. Linfadenite Caseosa. Sorologia.

\section{Introduction}

Goat farming is an extremely important activity of the northeastern region of Brazil, where 92.9\% and $59.8 \%$ of the goat and sheep population, respectively (IBGE, 2016) are concentrated. Goat farming is estimated to be present in more than one million of the rural establishments of Brazil, playing an important socio-economic role (MOREIRA; GUIMARÃES FILHO, 2011). However, high rates of morbidity and mortality occur in the caprine producing system of the region, caused mainly by the infectious diseases. This in turn results in serious economic losses to the productive chain, thus hindering the activity (PINHEIRO et al., 2000; MEDEIROS et al., 2005; ALENCAR et al., 2010).

Among these infectious diseases, we highlighted caseous lymphadenitis (CL), caused by Corynebacterium pseudotuberculosis, which is recognized by the formation of abscesses in the superficial or internal lymph nodes and organs (FACCIOLI-MARTINS et al., 2014). The damages caused by the disease are related to the impairment of organic functions, drop in productivity, reproductive problems, mastitis, skin depreciation, carcass condemnation, and even animal death. In Brazil, it is estimated that most of the goats and sheep are infected, mainly in the northeast region of Brazil, which contains majority of the national goat and sheep herds (ALVES et al., 2007).
There are several serological tests available for the diagnosis, such as ELISA (enzyme-linked immunosorbent assay), which has adequate sensitivity and specificity, and is very useful in studies of CL prevalence in herds, presenting as a diagnostic option in the disease control programs (FACCIOLI-MARTINS et al., 2014). Nonetheless, only a few serological surveys have been carried out in Brazil so far, probably due to the difficulties in obtaining supplies and the lack of necessary infrastructure to carry out the study (MARTINS et al., 2010).

The commercialization of the small ruminants in trade fairs is one of the main strategies of production distribution in the northeastern region of Brazil (NOGUEIRA FILHO et al., 2010). There are places where a substantial part of the goat and sheep production commerce occurs, by the farmers themselves or by the intermediary merchants, which involves acquiring the animals in the region's breeding farms and reselling them in these places. Animal fairs occur frequently, contributing to the growth and economic development of the interior cities of the Northeast (MAIA, 2007). Nevertheless, these agglomerations represent a serious problem related to the transmission of the infectious diseases to the herds due to the stringent contact and movement of the infected animals, vectors, and fomites (THRUSFIELD, 2007). 
Thus, information about CL epidemiology and the knowledge of disease transmission dynamics in the goat herds of the northeastern region is required, especially in the segments of higher risk, such as in animal agglomerations. Hence, the objective of this study was to determine the frequency of anti-C. pseudotuberculosis antibodies generated in the goats sold at the Tabira-PE animal fair of the northeastern semi-arid region, using the indirect ELISA technique.

\section{Material and Methods}

The study was conducted at the animal fair of the municipality of Tabira (latitude $07^{\circ} 35^{\prime} 31^{\prime \prime} \mathrm{S}$ and longitude $37^{\circ} 32^{\prime} 24^{\prime \prime} \mathrm{W}$ ), located in the Sertão do Pajeú, State of Pernambuco. The fair takes place biweekly, on Tuesdays and Wednesdays, receiving animals from Pernambuco and other states of the northeast. Cattle and small ruminants are the main animals sold, and due to the significant amount of sales, it is considered an important commercial center of the region.

The studied population comprised adult goats ( $>6$ months of age), of both genders, and without any defined racial pattern. To calculate the number of animals sampled, the following parameters were considered: (a). expected prevalence of $50 \%$ (used in order to maximize the sample); (b). absolute error of $7 \%$; and (c). 95\% confidence interval, according to the formula for simple random samples. According to these parameters, although the minimum sample "n" was 196 animals, 233 were used. The owners who participated in the survey were chosen by the convenience sampling method (THRUSFIELD, 2007).

The number of samples per collection was based on the total number of goats that participated in the fair during this period, which summed up to 16,434. These data were obtained from the report on the entry of animals, through the Animal Transit Guides (GTAs) presented by the owners. The data were provided by the Agricultural Protection and
Inspection Agency of the State of Pernambuco (ADAGRO). Nine owners accepted to participate in the research, signing the respective Informed Consent Form. The animals were selected randomly from the facilities where the herd commercialization was practiced. The collections were made from November 2014 to June 2015. Blood was collected from 233 goats. Of these, 206 originated from the State of Pernambuco and 27 from the State of Bahia.

The serological test used for the detection of anti-C. pseudotuberculosis antibodies was the indirect ELISA, according to the methodology described by Carminati (2005), using antigen produced from the sheep-strain in brain-heart broth with $0.1 \%$ Tween 80 and purified by three-phase partitioning (TPP), according to Paule et al. (2004). ELISA was carried out with the modifications developed by the Brazilian Agricultural Research Corporation (Embrapa Goats and Sheep, Sobral $\mathrm{CE})$.

The 96-well flat bottom polystyrene plate $\left(\mathrm{NUNC}^{\circledR}\right)$ was sensitized with $100 \mu \mathrm{l}$ of antigen per well, diluted in $0.05 \mathrm{M}$ carbonate-bicarbonate buffer ( $\mathrm{pH}$ 9.6) to a final concentration of $1.25 \mathrm{ng} /$ $\mu \mathrm{l}$ and incubated at $4^{\circ} \mathrm{C}$ overnight. Following this, the plate was washed twice with wash buffer (PBS with $0.05 \%$ Tween 20 ). The blocking step was then performed with $100 \mu \mathrm{l}$ of $2 \%$ casein solution (in PBS) per well, with subsequent incubation for 1 hour at $37^{\circ} \mathrm{C}$. After the washing step, $100 \mu \mathrm{l}$ of the $1: 100$ diluted serum (in PBS-T20 $+0.05 \%$ casein) was added, and the plate was incubated for 1 hour at $37^{\circ} \mathrm{C}$. For the positive and negative controls, goats' sera known to be positive (confirmed by microbiological examination) and negative (diseasefree herds) for C. pseudotuberculosis, respectively were used. A blank containing only the incubation buffer was used. Each of the serum and control was tested in duplicate. After the washing step, $100 \mu \mathrm{l} /$ well of rabbit total immunoglobulin goat anti-immunoglobulin conjugate (SIGMA ${ }^{\circledR}$ A5420), marked with peroxidases and diluted in the ratio of 1: 10,000 was added and incubated for 45 minutes 
at $37^{\circ} \mathrm{C}$. After the washing step, $100 \mu \mathrm{l} /$ well of developing solution ( $15 \mathrm{ml}$ of citric acid solution at $\mathrm{pH} 5.0+3 \mathrm{mg}$ of orthophenylenediamine $+3 \mu \mathrm{l}$ of $30 \%$ hydrogen peroxide) was added. The plate was incubated for 15 minutes at room temperature, in the dark. The reaction was stopped by adding $30 \mu \mathrm{l}$ of 5\% sulfuric acid. The ELISA reader (Multiskan ${ }^{\mathrm{TM}}$ FC Microplate Photometer) was then run at 492$\mathrm{nm}$ wavelength filter. This test had a sensitivity of $78.57 \%$ and specificity of $98.75 \%$.

The project was approved by the Research Ethics Committee (CEP) of the Rural Health and Technology Center (CSTR/UFCG) under the protocol number 098/2016.

\section{Results}

A total of 233 goat sera were examined for the presence of antibodies against C. pseudotuberculosis secreted antigens by the indirect ELISA method. Of the sera tested, 87 samples $(37.34 \%, 95 \%$ CI $=31.38-43.71 \%$ ) revealed a positive result. Of a total of 73 samples of male goats, $12(16.44 \%)$ were seropositive and of the 160 samples of female goats tested, 75 (46.88\%) presented positive serology (Table 1). Five of the nine studied properties (5/9, $55.55 \%$ ) were positive, presenting a proportion higher than $30 \%$ of the seropositive samples per property (Table 2).

Table 1. Frequency of goats tested for C. pseudotuberculosis by gender, sold at the animal fairs in the northeastern semi-arid region between November 2014 and June 2015.

\begin{tabular}{lccc}
\hline & & Goats & \\
& Males & Females & Total \\
\hline Positives & $12(16.4)$ & $75(46.88)$ & $\mathbf{8 7}(\mathbf{3 7 . 3 4})$ \\
Negatives & $61(83.56)$ & $85(53.12)$ & $\mathbf{1 4 6 ( 6 2 . 6 6 )}$ \\
\hline Total & $\mathbf{7 3 ( 1 0 0 . 0 )}$ & $\mathbf{1 6 0 ( 1 0 0 . 0 )}$ & $\mathbf{2 3 3 ( \mathbf { 1 0 0 . 0 } )}$ \\
\hline
\end{tabular}

Table 2. Frequency of municipalities and source properties of goats tested for C. pseudotuberculosis, sold at an animal fair in the municipality of Tabira - PE in the northeastern semi-arid region between November 2014 and June 2015.

\begin{tabular}{lcccc}
\hline Municipality/Origin & Tested Properties & Positives & Tested Animals & Positives (\%) \\
\hline Casa Nova - BA & 1 & 1 & 25 & $11(44.00)$ \\
Remanso - BA & 1 & - & 2 & - \\
Tabira - PE & 2 & 1 & 63 & $26(41.26)$ \\
Calumbi - PE & 1 & - & 2 & - \\
Sertânia - PE & 1 & - & 6 & - \\
São José do Egito - PE & 1 & 1 & 55 & $18(32.72)$ \\
Brejinho - PE & 1 & 1 & 30 & $15(50.00)$ \\
Santa Terezinha - PE & 1 & 1 & 50 & $17(30.91)$ \\
Total & $\mathbf{9}$ & $\mathbf{5}$ & $\mathbf{2 3 3}$ & $\mathbf{8 7}(\mathbf{3 7 . 3 4 )}$ \\
\hline
\end{tabular}

\section{Discussion}

The diagnosis of C. pseudotuberculosis infection can be performed mainly through bacterial isolation and identification, serological techniques, and polymerase chain reaction (OREIBY, 2015). The isolation and identification of the agent in caseous material drained from the abscesses or organs is 
considered as the gold standard for the diagnosis of CL (BAIRD; FONTAINE, 2007). Nevertheless, some infected animals may not show the clinical signs such as abscess formation, which may be a limiting factor in performing the technique. Hence, serological techniques that have adequate sensitivity and specificity are indicated for the disease diagnosis, since they have the advantage of identifying the infection in situations where the animals present compatible clinical symptomatology (BINNS et al., 2007).

Among the serological techniques for $\mathrm{CL}$ diagnosis, ELISA is an important technique. According to Faccioli-Martins et al. (2014), various improvements have made it possible for the use of this assay in disease-control programs. The advantages are cost-benefit, ease of application, and acceptable sensitivity and specificity (OREIBY, 2015). Nassar et al. (2014) reported other advantages like shorter test time, ease of antigen preparation, and the use of small quantity of inputs, make the use of this test possible for disease diagnosis in the epidemiological studies and for commercial purposes. Thus, in addition to facilitating CL diagnosis in herds, ELISA contributes to disease control in situations where clinical symptoms are not evident, in turn becoming an important emerging tool to be used in the implementation of disease-control programs in Brazil. In this study, the use of this test for the diagnosis of CL allowed the epidemiological diagnosis of the disease at the site of agglomeration and commercialization of small ruminants, proving that the use of this technique as a diagnostic tool in these situations is useful and effective.

The use of ELISA for the diagnosis of CL in Netherlands (DERCKSEN et al., 2000), Germany (KABA et al., 2001; STING et al., 2012), and Canada (MENZIES et al., 2004) demonstrated sensitivity and specificity variations between $81 \%$ - $97 \%$ and $96 \%$ - 99\%, respectively, due to the different standardizations of antigens produced from bacterial cells, exotoxins, and interferon- $\gamma$. In Brazil, Carminati et al. (2003) developed and standardized an indirect ELISA using the antigens obtained from culture supernatant of C. pseudotuberculosis, with sensitivity and specificity of $93.5 \%$ and $100 \%$, respectively. Zerbinati et al. (2007) standardized an indirect ELISA with sensitivity and specificity of $99.8 \%$ and $98.0 \%$, respectively, using the purified bacterial protein antigen. The indirect ELISA test used in this study, using a TPP-derived antigen of secreted proteins, had a better efficiency as compared to the other tests such as the sandwich ELISA. Additionally, the indirect ELISA using antigens not obtained by TPP, as described by Carminati (2005), showed a greater reliability in the use of this technique for disease diagnosis.

Few serological surveys for C.pseudotuberculosis in small ruminants have been conducted in Brazil using indirect ELISA. In Minas Gerais, Guimarães et al. (2009) observed seropositivity of $70.9 \%$ in sheep. Later, seropositivity of $78.9 \%$ in goats (SEYFFERT et al., 2010) and $43.7 \%$ in sheep was found (GUIMARÃES et al., 2011a). In the State of Ceará, Carmo et al. (2009) found seropositivity of $26.2 \%$ in goats. In the Federal District, Carmo et al. (2012) observed a prevalence of $44.0 \%$ in sheep. In Bahia, studies by Martins et al. (2010) showed $27.54 \%$ of seropositivity in sheep. In Pernambuco, Martins et al. (2011) observed $54.98 \%$ of seropositive sheep. Despite the significant differences between the results found in the above-mentioned studies as well as the other studies, it is noted that the disease is indeed widespread in the country, with a high frequency of seropositive animals.

The seropositive properties observed in this study $(55.55 \%)$ are similar to the results obtained by Carmo et al. (2012) in the Federal District and by Martins et al. (2010) in Bahia, who observed a seropositivity of $50 \%$ and $56 \%$, respectively. Nevertheless, it was lower than the result obtained by Carmo et al. (2009), who found that seropositivity was $82.7 \%$ in Ceará and $95.9 \%$ to $100 \%$ in Minas Gerais (GUIMARÃES et al., 2009; SEYFFERT et al., 2010). However, the results from the study reveal that a high percentage of positive properties 
with a high number of seropositive goats are found in each property studied.

Studies using the isolation agent were performed in Paraíba by Andrade et al. (2012), which evaluated goats and sheep in the semi-arid region of Brazil, where they observed $7.7 \%$ of the animals with clinical signs of CL and isolated the agent in $68.2 \%$ of the samples. Souza et al. (2011) evaluated sheep slaughtered in a municipality in the Cariri region of Paraíba, originated in Bahia, Pernambuco, and Paraíba; the macroscopic lesions like CL were identified in $15.9 \%$ of the inspected animals and C. pseudotuberculosis was isolated in $74.5 \%$ of the cultured samples. These results reinforce the need for more comprehensive serological studies, making it possible for the development of control measures for this disease in goats and sheep in the region.

In this study, the frequency of seropositivity in females $(46.88 \%)$ was significantly higher than that found in males (16.44\%). In another study, Souza et al. (2011) demonstrated a higher frequency of agent isolation in the females $(17.9 \%)$ than in males $(13.8 \%)$. The authors attributed this fact to the greater slaughter age of females due to their long stay in the farms as compared to that of the males. Thus, the former would have greater chances of acquiring the infection. In addition, the seropositive animals contributed to the maintenance and heightened the risk of disease transmission in the herd.

The infected animals, with or without clinical symptoms, are considered the main source of infection and can contaminate soil, water, food, pastures, and facilities, through the nasal secretions, feces, and pus from the contaminated abscesses (GUIMARÃES et al., 2011b). The introduction of sick animals into the herds facilitates the disease transmission. An important control measure by the breeders would be to avoid the acquisition of these animals. It is common practice to buy goats at animal fairs in the northeast, where the owners acquire them, and later introduce them to the farm herds (NOGUEIRA FILHO et al., 2010). In this case, the commercialization of infected animals in such events can act as a facilitator of disease spread. Therefore, control measures contributing to the prevention of the entry of such animals should be implemented.

One aspect that should be considered is the breeding system practiced by the animal traders. They acquire species such as goats, sheep, and cattle from the region's owners through purchase and keep them confined in small spaces until the time of sale. This breeding system presents peculiarities such as intensive breeding, in contrast to the extensive and semi-intensive systems that are generally practiced by most of the owners of the Brazilian Northeast (GUILHERME et al., 2017). It should be emphasized that intensive breeding is a determinant condition for high CL prevalence due to the confinement of animals in a small space, particularly when there is inadequate control of the disease in such spaces (SOUZA et al., 2011). Therefore, this study suggested that the confinement condition of intensive breeding may favor CL transmission among herd animals.

Studies have cited that animal traffic is an important risk factor for disease dissemination (BIGRAS-POULIN et al., 2007; CAPANEMA et al., 2012). This raises the possibility of CL transmission through movement and close contact between the infection sources, susceptible vectors, and interferences at the agglomeration site, as well as the traffic between region's goat and sheep breeding farms to the animal fairs. Alves et al. (2017) emphasized the epidemiological importance of the Tabira - PE animal fair of the northeastern semi-arid region, since the animals traded in that place originate mainly in the states such as Bahia, Pernambuco, and Paraíba and are moved to several municipalities of these and other states of the northeast region. In this way, this event can act as a facilitator of spread of diseases such as CL, since infected animals can be bought by owners of several regions, becoming disseminators of this disease after being introduced to the healthy herds. 


\section{Conclusion}

It is suggested that C. pseudotuberculosis infection is widespread in goats sold at the animal fairs. This study highlights the importance of indirect ELISA in disease diagnosis in goat herds, mainly due to the rapidity and ease of the technique, which allows the implementation of this method in disease-control programs in the region's breeding farms, animal transportation inspection sites, and in animal agglomerations.

\section{Acknowledgement}

We would like to thank the National Council for Scientific and Technological Development (CNPq), for granting the scholarship and financial support necessary for the development of the project, and Embrapa Caprinos: CNPC Sobral - CE for providing space and materials needed to carry out the serological tests.

\section{References}

ALENCAR, S. P.; MOTA, R. A.; COELHO, M. C. O. C.; NASCIMENTO, S. A.; ABREU, S. R. O.; CASTRO, R. S. Perfil sanitário dos rebanhos caprinos e ovinos no sertão de Pernambuco. Ciência Animal Brasileira, Goiânia, v. 11, n. 1, p. 131-140, 2010.

ALVES, F. S. F.; SANTIAGO, L. B.; PINHEIRO, R. R. Linfadenite Caseosa: o estado da arte. Sobral: EMBRAPA-CNPC, 2007. 57 p. (EMBRAPA-CNPC. Documentos, 74).

ALVES, J. R. A.; LIMEIRA, C. H.; LIMA, G. M. S.; PINHEIRO, R. R.; ALVES, F. S. F.; SANTOS, V. W. S.; AZEVEDO, S. S.; ALVES, C. J. Epidemiological characterization and risk factors associated with lentiviral infection of small ruminants at animal fairs in the semiarid Sertão region of Pernambuco, Brazilian semiarid. Semina: Ciências Agrárias, Londrina, v. 38, n. 4, p. 1875-1886, 2017.

ANDRADE, J. S. L.; AZEVEDO, S. S.; TELES, A. J. A.; HIGINO, S. S. S.; AZEVEDO, E. O. Ocorrência e fatores de risco associados à infecção por Corynebacterium pseudotuberculosis em caprinos e ovinos do semiárido paraibano. Pesquisa Veterinária Brasileira, Seropédica, v. 32, n. 2, p. 116-120, 2012.
BAIRD, G. J.; FONTAINE, M. C. Corynebacterium pseudotuberculosis and its role in ovine caseous lymphadenitis. Journal of Comparative Pathology, Edinburgh, v. 137, n. 4, p. 179-210, 2007.

BIGRAS-POULIN, M.; BARFOD, K.; MORTENSEN, S.; MATTHIAS, G. Relationship of trade patterns of the Danish swine industry animal movements network to potential disease spread. Preventive Veterinary Medicine, Londres, v. 80, n. 2-3, p. 143-165, 2007.

BINNS, S. H.; GREEN, L. E.; BAILEY, M. Development and validation of ELISA to detect antibodies to Corynebacterium pseudotuberculosis in ovine sera. Veterinary Microbiology, Amsterdam, v. 123, n. 1-3, p. 169-179, 2007.

CAPANEMA, R. O.; HADDAD, J. P. A.; FELIPE, P. L. S. Trânsito de bovinos nos estados do Mato Grosso e Mato Grosso do Sul, Brasil. Arquivo Brasileiro de Medicina Veterinária e Zootecnia, Belo Horizonte, v. 64, n. 2, p. 253-262, 2012.

CARMINATI, R. Estudo da sensibilidade e especificidade de quatro testes ELISA e utilização da técnica de PCR para o diagnóstico de linfadenite caseosa em caprinos. 2005. Dissertação (Mestrado em Imunologia) - Instituto de Ciências da Saúde da Universidade Federal da Bahia, Salvador.

CARMINATI, R.; BAHIA, R.; COSTA, L. F. M.; PAULE, B. J. A.; VALE, V. L.; REGIS, L.; FREIRE, S. M.; NASCIMENTO, I.; SCHAER, R.; MEYER, R. Determinação da sensibilidade e da especificidade de um teste de ELISA indireto para o diagnóstico de linfadenite caseosa em caprinos. Revista de Ciências Médicas e Biológicas, Salvador, v. 2, n. 1, p. 88-93, 2003.

CARMO, F. B.; GOUVEIA, A. M. G.; GUIMARÃES, A. S.; PAULETTI, R. B.; LAGE, A. P.; FERREIRA, F.; PORTELA, R. W. D.; PINHEIRO, R. R.; AZEVEDO, V. A. C.; HEINEMANN, M. B. Soroprevalência da linfadenite caseosa em caprinos em propriedades do Estado do Ceará. In: CONGRESSO BRASILEIRO DE MiCROBIOLOGIA, 25., 2009, Porto de Galinhas. Resumos... São Paulo: SBM, 2009. CD-ROM.

CARMO, F. B.; GUIMARÃES, A. S.; PAULETTI, R. B.; LAGE, A. P.; GOLÇALVES, V. S. P.; MEYER, R.; PORTELA, R. W. D.; MIYOSHI, A.; AZEVEDO, V.; GOUVEIA, A. M. G.; HEINEMANN, M. B. Prevalência de anticorpos contra a linfadenite caseosa em criações comerciais de ovinos no Distrito Federal, Brasil. Arquivos do Instituto Biológico, São Paulo, v. 79, n. 2, p. 293-298, 2012 .

DERCKSEN, D. P.; BRINKHOF, J. M. A.; DEKKERNOOREN, T.; MAANEN, K. V.; BODE, C. F.; BAIRD, 
G.; KAMP, E. M. A comparison of four serological tests for the diagnosis of caseous lymphadenitis in sheep and goats. Veterinary Microbiology, Amsterdam, v. 75, n. 2, p. $167-175,2000$.

FACCIOLI-MARTINS, P. Y.; ALVES, F. S. F.; PINHEIRO, R. R. Linfadenite caseosa: perspectivas no diagnóstico, tratamento e controle. Sobral: EMBRAPA Caprinos e Ovinos, 2014. 71 p. (Documentos, EMBRAPA Caprinos e Ovinos, 113). Disponível em: <http://www. cnpc.embrapa.br/publicacoes/>. Acesso em: 14 set. 2015.

GUILHERME, R. F.; LIMA, A. M. C.; ALVES, J. R. A.; COSTA, D. F.; PINHEIRO, R. R.; ALVES, F. S. F.; AZEVEDO, S. S.; ALVES, C. J. Characterization and typology of sheep and goat production systems in the State of Paraíba, a semi-arid region of northeastern Brazil. Semina: Ciências Agrárias, Londrina, v. 38, n. 4, p. 2163-2178, 2017.

GUIMARÃES, A. S.; CARMO, F. B.; HEINEMANN, M. B.; PORTELA, R. W. D.; MEYER, R.; LAGE, A. P.; SEYFFERT, N.; MIYOSHI, A.; AZEVEDO, V.; GOUVEIA, A. M. G. High sero-prevalence of caseous lymphadenitis identified in slaughterhouse samples as a consequence of deficiencies in sheep farm management in the state of Minas Gerais, Brazil. BMC Veterinary Research, Londres, v. 7, n. 68, p. 1-5, 2011a.

GUIMARÃES, A. S.; CARMO, F. B.; PAULETTI, R. B.; SEYFFERT, N.; RIBEIRO, D.; LAGE, A. P.; HEINEMANN, M. B.; MIYOSHI, A.; AZEVEDO, V.; GOUVEIA, A. M. G. Caseous lymphadenitis: epidemiology, diagnosis, and control. The IIOAB Journal, West Bengal, v. 2, n. 2, p. 33-43, 2011 b.

GUIMARÃES, A. S.; SEYFFERT, N.; BASTOS, B. L.; PORTELA, R. W. D.; MEYER, R.; CARMO, F. B.; CRUZ, J. C. M.; McCULLOCH, J. A.; LAGE, A. P.; HEINEMANN, M. B.; MIYOSHI, A.; AZEVEDO, V.; GOUVEIA, A. M. G. Caseous lymphadenitis in sheep flocks of the state of Minas Gerais, Brazil: prevalence and management surveys. Small Ruminant Research, Amsterdam, v. 87, n. 1-3, p. 86-91, 2009.

INSTITUTO BRASILEIRO DE GEOGRAFIA E ESTATÍSTICA - IBGE. Pesquisa Pecuária Municipal. Rio de Janeiro: IBGE, 2016. Disponível em: < http://www. sidra.ibge.gov.br/bda/tabela/listabl.asp? $\mathrm{z}=\mathrm{t} \& \mathrm{o}=24 \& \mathrm{i}=$ $P \& c=3939>$. Acesso em: 26 dez. 2017.

KABA, J.; KUTSCHKEB, L.; GERLACHC, G. F. Development of an ELISA for the diagnosis of Corynebacterium pseudotuberculosis infections in goats. Veterinary Microbiology, Amsterdam, v. 78, n. 2, p. 155163, 2001.

MAIA, D. S. A feira de gado na cidade: encontros, conversas e negócios. Revista Formação, Presidente
Prudente, v. 1, n. 14, p. 12-30, 2007.

MARTINS, R. J.; VESCHI, J. L. A.; CARMO, F. B.; AZEVEDO, V.; SEYFFERT, N.; MIYOSHI, A.; MEYER, R.; PORTELA, R.; PEIXOTO, R. M.; COSTA, M. M.; ZAFALON, L. F.; GOUVEIA, A. M. G. Avaliação da presença de anticorpos anti-Corynebacterium pseudotuberculosis em caprinos leiteiros do Território do Sisal, BA. In: JORNADA DE INICIAÇÃO CIENTÍFICA DA EMBRAPA SEMIÁRIDO, 5., 2010, Petrolina. Anais... Petrolina: EMBRAPA Semiárido, 2010. p. 2531. Disponível em: $<$ http://www.alice.cnptia.embrapa.br/ handle/doc/873277 >. Acesso em: 10 abr. 2016.

MARTINS, R. J.; VESCHI, J. L. A.; LANDIM, A. M. S.; CARMO, F. B.; AZEVEDO, V.; MIYOSHI, A.; MEYER, R.; PORTELA, R.; ZAFALON, L. F.; GOUVEIA, A. M. G. Avaliação da presença de anticorpos anti- Corynebacterium pseudotuberculosis em ovinos do Município de Dormentes, PE. In: JORNADA DE INICIAÇÃO CIENTÍFICA DA EMBRAPA SEMIÁRIDO, 6., 2011, Petrolina, Anais... Petrolina: EMBRAPA Semiárido, 2011. p. 397-403. Disponível em: <http://ainfo.cnptia.embrapa.br/digital/bitstream/ item/46305/1/79-Raiane.pdf>. Acesso em: 10 abr. 2016.

MEDEIROS, J. M.; TABOSA, I. M.; SIMÕES, S. V. D.; NÓBREGA JÚNIOR, J. E.; VASCONCELOS, J. S.; RIET-CORREA, F. Mortalidade perinatal em caprinos no Semiárido da Paraíba. Pesquisa Veterinária Brasileira, Seropédica, v. 25, n. 4, p. 201-206, 2005.

MENZIES, P. I.; HWANG, Y-T.; PRESCOTT, J. F. Comparison of an interferon- interferon- $\gamma$ to a phospholipase D enzyme-linked immunosorbent assay for diagnosis of Corynebacterium pseudotuberculosis infection in experimentally infected goats. Veterinary Microbiology, Amsterdam, v. 100, n. 1-2, p. 129-137, 2004.

MOREIRA, J. N.; GUIMARÃES FILHO, C. Sistemas tradicionais para a produção de caprinos e ovinos. In: VOLTOLINI, T. V. (Ed.). Produção de caprinos e ovinos no semiárido. Petrolina: EMBRAPA Semiárido, 2011. cap. 2, p. 49-68.

NASSAR, A. F. C.; MIYASHIRO, S.; GREGORY, F.; PIATTI, R. M.; DANIEL, G. T.; GREGORY, L. Standardization of an enzyme-linked immunosorbent assay (ELISA) for detection of antibodies antiCorynebacterium pseudotuberculosis in sheep. Small Ruminant Research, Amsterdam, v. 116, n. 2-3, p. 229232, 2014.

NOGUEIRA FILHO, A.; FIGUEIREDO JÚNIOR, C. A.; YAMAMOTO, A. Mercado de carne, leite e pele de caprinos e ovinos no Nordeste. Fortaleza: Banco do Nordeste do Brasil, 2010. 128 p. 
OREIBY, A. F. Diagnosis of caseous lymphadenitis in sheep and goat. Small Ruminant Research, Amsterdam, v. 123, n. 1, p. 160-166, 2015.

PAULE, B. J. A.; MEYER, R.; MOURA-COSTA, L. F.; BAHIA, R. C.; CARMINATI, R.; REGIS, L. F.; VALE, V. L. C.; FREIRE, S. M.; NASCIMENTO, I.; SCHAER, R.; AZEVEDO, V. Three-phase partitioning as an efficient method for extraction/concentration of immunoreactive excreted-secreted proteins of Corynebacterium pseudotuberculosis. Protein Expression and Purification, San Diego, v. 34, n. 2, p. 311-316, 2004.

PINHEIRO, R. R.; GOUVEIA, A. M. G.; ALVES, F. S. F.; HADDAD, J. P. A. Aspectos epidemiológicos da caprinocultura cearense. Arquivo Brasileiro de Medicina Veterinária e Zootecnia, Belo Horizonte, v. 52, n. 5, p. 534-543, 2000.

SEYFFERT, N.; GUIMARÃES, A. S.; PACHECO, L. G. C.; PORTELA, R. W.; BASTOS, B. L.; DORELLA, F. A.; HEINEMANN, M. B.; LAGE, A. P.; GOUVEIA, A. M. G.; MEYER, R.; MIYOSHI, A.; AZEVEDO, V. High seroprevalence of caseous lymphadenitis in Brazilian goat herds revealed by Corynebacterium pseudotuberculosis secreted proteins-based ELISA. Research in Veterinary Science, Londres, v. 88, n. 1, p. 50-55, 2010.
SOUZA, M. F.; CARVALHO, A. Q.; GARINO, J. R. F.; RIET-CORREA, F. Linfadenite caseosa em ovinos deslanados abatidos em um frigorifico da Paraíba. Pesquisa Veterinária Brasileira, Seropédica, v. 31, n. 3, p. 224-230, 2011.

STING, R.; WAGNER, B.; SARI-TURAN, A.; STERMANN, M.; RUELE, M.; EICHNER, M.; BEYER, W. Serological studies on Corynebacterium pseudotuberculosis infections in goats in BadenWuerttemberg (Germany) and seroreactions on antigens used for newly developed Enzyme-Linked Immunosorbent Assays (ELISA). Berliner und Munchener Tierarztliche Wochenschrift, Berlim, v. 125, n. 1-2, p. 67-75, 2012.

THRUSFIELD, M. Veterinary epidemiology. $3^{\text {th }}$ ed. Oxford: Blackwell Science, 2007. 624 p.

ZERBINATI, J.; GREVE, I. C.; LEAL, R. F.; AMORIM, L. M. P. V.; SILVA, D. L.; VIEGAS, S. R. A. A.; PEIXOTO, A. P. C.; CARMINATI, R.; CERQUEIRA, R. B. Produção e padronização de um antígeno para um teste ELISA indireto no diagnóstico da linfadenite caseosa em soros caprinos. Revista Acadêmica, Curitiba, v. 5, n. 3, p. 285-293, 2007. 
